\title{
Da'i Muda Pilihan (DMP) ANTV dalam Perspektif Dakwah
}

\author{
Fatmawati \\ UIN Syarif Hidayatullah Jakarta \\ E-mail: fatmawatisofyan@yahoo.com
}

\begin{abstract}
This paper attempts to unravel the involvement of media in orbit would-be preachers and da'iah as a television program. The position of television as a medium to be very important in clarifying the boundaries of da'iah professionalism because a preacher or items related to the assessment standards applied by the media as an organizer of the contest. In addition, this paper also presents the phenomenon of young preachers that the selection program is a form of positive cooperation between the Islamic syi'ar the media so that the message of Islam can exist in the development of information and communication technology is rapidly increasing.
\end{abstract}

\section{Kata Kunci:}

Da'i Muda Pilihan, Kode Etik Da'i, Sifat Da'i

\section{A. Pendahuluan}

Secara normatif, dakwah merupakan suatu kemestian dalam rangka pengembangan agama Islam, aktivitas dakwah yang maju dan kreatif akan membawa pengaruh terhadap kemajuan agama, sebaliknya, aktivitas dakwah yang tidak kreatif akan berakibat pada kejenuhan dan kejumudan sehingga terjadi kepunahan dalam beragama. Dengan demikian benar Allah SWT meletakkan kewajiban dakwah sebagai kewajiban individu (fardu 'ain).

Islam sebagai al-Dîn Allah (QS. Ali Imran: 85) merupakan manhâj al-hayât atau way of life, acuan dan kerangka tata nilai kehidupan. Oleh karena itu, ketika komunitas yang ditegakkan di atas sendi-sendi moral iman, Islam dan takwa serta dapat direalisasikan dan dipahami secara utuh, yaitu sebagai teladan ditengah arus kehidupan yang serba 
kompleks, penuh dengan dinamika perubahan, tantangan dan pilihanpilihan yang terkadang sangat dilematis.

Dakwah bukan saja merupakan keharusan melainkan merupakan tugas terbesar kaum muslim yang mesti ditunaikan. Oleh sebab itu dapat dimengerti bila semangat untuk menyampaikan dan memperjuangkan semangat Islam terus membara dalam jiwa kaum muslimin. Bahkan citacita hidup seorang muslim menurut al-Faruqi ialah membawa manusia kedalam suatu kehidupan di mana Islam agama Allah yang benar dalam semua aspeknya, baik teologi, hukum, akhlak dan istitusi-institusi Islam dapat diterima dan menjadi agama (system hidup) seluruh umat manusia (Ridho, 1985: 83, Lihat juga dalam Hasim, 1990: 5).

Agama Islam merupakan agama dakwah baik secara teoritis maupun praktis, yakni agama yang mengharuskan kepada para pemeluknya untuk menyampaikan kebenaran agama tersebut kepada orang lain, bahkan kepada seluruh umat manusia (Arnold, 1995: 1, Lihat juga Poston, 1992: 3, dan Mahmud, 1969: 34). Sebagai agama dakwah, kedudukan Islam menurut al-Faruqi (1986: 188), melebihi agama-agama dakwah yang lain. Hal ini disebabkan oleh klaim Islam sendiri bahwa Islam merupakan wahyu (agama) terakhir dan merupakan agama penyempurna (reformasi definitif) dari agama-agama sebelum-nya, terutama agama Yahudi dan Nasrani.

Al-Faruqi menegaskan dengan mengutip beberapa ayat al-Qur'an diantaranya:

Q.S. asy-Syuura: 15; Artinya: "Maka karena itu serulah mereka kepada agama itu dan tetaplah dalam agama dan lanjutkanlah dakwah sebagaimana diperintahkan kepadamu..."

Q.S. an-Nahl: 25; Artinya: "Serulah manusia kepada jalan Tuhanmu dengan hikmah dan pelajaran yang baik dan bantahlah mereka dengan cara yang baik pula..."

Q.S. Fushshilat: 33; Artinya: "Siapakah yang lebih baik perkataannya dari pada orang yang menyeru kepada Allah, mengerjakan amal shaleh dan berkata sesungguhnya aku termasuk orang-orang yang menyerah diri."

Aktivitas dakwah pada awalnya hanyalah merupakan tugas untuk menyampaikan apa yang diterima dari Rasulullah Saw, walaupun hanya satu ayat, hal ini dapat dipahami sebagaimana yang ditegaskan oleh hadits Rasulullah saw, "Ballighû 'anni walau ayat" inilah yang membuat 
aktivitas dakwah harus dilakukan oleh siapa saja yang mempunyai rasa keterpanggilan untuk menyebarkan nilai-nilai Islam. Itulah sebabnya aktivitas dakwah harus berangkat dari kesadaran pribadi yang dilakukan oleh orang perorang dengan kemampuan minimal dari siapa saja yang dapat melakukan dakwah terebut.

Seperti diketahui, Nabi Muhammad Saw. sendiri telah melaksanakan dakwah dengan sebaik-baiknya sejak pertama kali beliau menerima risalah Islam hingga akhir hayatnya, dengan demikian beliau adalah da'i pertama dalam Islam (Zaidan, 1992 dan Al-Ghazali, t.th: 122). Selanjutnya sahabat-sahabat beliau mengikuti jejaknya. Mereka pun mengemban amanah Islam ini sepenuh hati dan melaksanakan dengan sebaik-baiknya berkat pemahaman mereka yang mendalam terhadap petunjuk dan sunnah Rasul (Mahfudz, t.th: 14-15, lihat pula al-Khaliq, 1983: 11).

Tampilnya da'i-da'i dan da'iah-da'iah muda yang dikemas dalam program Da'i Muda Pilihan (DMP) ANTV 2011/2012 yang hanya berkisar enam bulan dan ditayangkan setiap malam Minggu oleh stasiun televisi ANTV dalam bentuk kompetisi. Hal ini merupakan satu metode dakwah yang baru dan kreatif di era globalisasi ini dan menjawab kebutuhan umat Islam modern, tentu dalam rangka mengemban risalah yang dibawa Nabi Muhammad SAW secara efektif dan menarik.

\section{B. Pembahasan}

Dakwah menurut bahasa berarti ajakan, seruan, undangan dan panggilan. Sedangkan menurut istilah dakwah berarti menyeru untuk mengikuti sesuatu dengan cara dan tujuan tertentu. Sedangkan pengertian dakwah Islam adalah menyeru ke jalan Allah yang melibatkan unsurunsur penyeru (da'i dan da'iah), masyarakat yang diseru (mad'û), media, dan metode dakwah. Sedangkan menurut al-Bahiy, dakwah Islam berarti mengubah suatu situasi ke situasi yang lebih baik sesuai dengan ajaran Islam (Kusnawan et al., 2004: vii).

Dalam dakwah terdapat dua dimensi besar yang mencakup penyampaian pesan kebenaran, yaitu pertama, dimensi kerisalahan (bi ahsan al qawl), merupakan tuntunan dari Q.S. al-Maidah: 67 dan Q.S. alImran: 104. Dimensi kerisalahan dakwah mencoba menumbuhkan kesadaran diri (individu/masyarakat) tentang kebenaran nilai dan pandangan hidup secara Islam, sehingga terjadi proses internalisasi nilai Islam sebagai nilai hidup, dengan kata lain dakwah kerisalahan dalam 
prakteknya merupakan proses mengkomunikasikan dan menginternalisasikan nilai-nilai Islam, dalam hal ini (a) Islam merupakan sumber nilai, dan (b) dakwah sebagai proses alih nilai.

Kedua, mencakup pengaplikasian nilai kebenaran yang merupakan kerahmatan (bi ahsan al-'amal), mengacu pada firman Allah Q.S. alAnbiya': 107. Dakwah kerahmatan ini merupakan upaya mengaktualisasikan Islam sebagai rahmat (jalan hidup yang menyejahterakan, membahagiakan, dan sebagainya) dalam kehidupan umat manusia. Dengan begitu, jika dalam dimensi kerisalahan dakwah lebih cocok sebagai "mengenalkan Islam", maka dalam dimensi kerahmatan, dakwah merupakan upaya mewujudkan Islam dalam kehidupan (Kusnawan, et al., 2004: viii).

\section{Dakwah Masa Rasulullah}

Dakwah masa Rasulullah terbagi dua periode diantaranya periode Makkah dan periode Madinah. Tentang jejak dakwah Rasulullah SAW di Jazirah Arabia dilukiskan Amin Said dengan ringkas bahwa seungguhnya Nabi Muhammad SAW telah membawa agama yang paling utama dan paling sempurna yang dalam waktu tidak berapa lama berkembang ia di empat penjuru dunia, dimana manusia berbondong-bondong masuk kedalamnya, Nabi Muhammad telah menyusun satu syari'at, dimana para peneliti terkemuka telah sepakat, bahwa syari'at Nabi Muhammad SAW adalah syari'at samawi yang paling maju dikenal sejarah manusia. Nabi Muhammad SAW telah membangun sistem masyarakat baru atas dasar persaudaraan, persamaan dan kemerde-kaan. Ia adalah sistem masyarakat yang paling maju yang pernah dikenal di Jazirah Arabia, sehingga ia dapat mempengaruhi dunia dan dapat menaklukkan beberapa kerajaan besar, dapat membangun pemerintahan yang adil, dapat menghapus dan memerangi bid'ah dan khurafat (Saputra, 2011: 40).

Karena merupakan suatu kebenaran, maka Islam harus tersebar luas dan penyampaian kebenaran tersebut merupakan tanggung jawab umat Islam secara keseluruhan. Sesuai dengan misinya sebagai rahmatan lîal-'âlamîn, Islam harus tampil dengan wajah yang menarik supaya umat lain mempunyai pandangan bahwa kehadiran Islam bukan sebagai ancaman bagi eksistensi mereka melainkan pembawa keda-maian dan ketenteraman dalam kehidupan mereka sekaligus sebagai pengantar menuju kebahagiaan kehidupan dunia dan akhirat.

Rasulullah adalah sosok pribadi yang sangat berhasil, baik dalam 
kedudukannya sebagai hamba Allah, sebagai Rasul, maupun sebagai model kehidupan manusia yang layak diteladani oleh para pengikutnya hingga akhir zaman. Mengingat Rasulullah adalah sebagai model kehidupan, maka meneladani Rasulullah adalah jalan bebas hambatan menuju keberhasilan. Paling tidak ada tiga hal yang berkaitan dengan kehidupan Rasulullah, yaitu sunnah Rasulullah, sejarah Rasulullah, sifat Rasulullah dan akhlaq Rasulullah.

Dakwah yang disampaikan Rasulullah Saw kepada umat manusia memiliki keistimewaan. Rasul memiliki karakter yang sangat berbeda dari para raja, presiden, atau para tokoh lainnya. Perbedaan itu terletak dalam segi karakter, perasaan, tingkah laku, amal perbuatan maupun orietensi tujuan hidup. Setiap individu yang telah dikader Rasulullah merupakan teladan pendidikan Nabi yang menjadi kebanggaan manusia. Didikan Nabi membuat mereka memiliki iman yang kokoh, berilmu luas, bersikap jujur, bersikap rendah hati dan memiliki kesadaran memelihara diri dari dosa (Sadel, 1996: 650).

\section{Model Dakwah Modern}

Perkembangan masyarakat yang semakin meningkat semua aspek kehidupan, tuntutan pun semakin beragam, membuat dakwah tidak bisa lagi dilakukan secara tradisional, dakwah sekarang sudah berkembang menjadi satu profesi yang menuntut skill, planning dan manjemen yang handal, untuk diperlukan sekelompok atau perorangan yang secara terus menerus mengkaji, meneliti dan melakukan aktivitas dakwah secara profesional. Hal inilah yang ditegaskan dalam al-Qur'an (QS. Ali-Imran: 104).

Memahami esensi dari makna dakwah itu sendiri, kegiatan dakwah sering dipahami sebagai upaya untuk memberikan solusi Islam terhadap berbagai masalah dalam kehidupan. Masalah kehidupan tersebut mencakup seluruh aspek, seperti; aspek ekonomi, sosial, budaya, hukum, politik, sains, teknologi, dan sebagainya.

Untuk itu dakwah haruslah dikemas dengan cara dan metode yang tepat dan pas. Dakwah harus tampil secara aktual, faktual dan kontekstual. Aktual dalam arti memecahkan masalah yang kekinian dan hangat di tengah masyarakat. Faktual dalam arti konkrit dan nyata, serta kontekstual dalam arti relevan dan menyangkut problema yang sedang dihadapi oleh masyarakat.

Oleh sebab itu, memilih cara dan metode yang tepat, agar dakwah 
menjadi aktual, faktual dan kontekstual, menjadi bahagian strategis dari kegiatan dakwah itu sendiri. Literatur dakwah dalam membicarakan metode atau model dakwah, selalu merujuk pada Firman Allah SWT, dalam al-Qur'an (QS. An-Nahl: 125).

Dakwah kontemporer merupakan metode dakwah yang digunakan para da'i dan da'iah pada zaman sekarang yang sudah ditambah dengan teknik-teknik metode dakwah yang lebih canggih dan lebih kreatif sehingga metode educative dan entertaiment (edu-taiment) menjadi penting dan ternyata mendapat respon yang positif dari mad'u masa kini terutama kalangan muda terbukti dengan animo masyarakat yang datang kangsung ke studio ANTV untuk menyaksikan langsung para kontestan da'i dan da'iah meskipun diadakan pada malam hari namun tidak mengurangi animo masyarakat untuk datang ke stasiun ANTV di Kuningan Jakarta Pusat, sedangkan dari rating-nya pun mengejutkan karena di atas standar yang berarti masyarakat di rumah pun banyak yang menonton acara Da'i Muda Pilihan ANTV.

Dakwah Bi al-Lisân yaitu: penyampaian informasi atas pesan dakwah melalui lisan (ceramah atau komunikasi langsung antara subjek dan objek dakwah), yang dimaksud dengan efektifitas dakwah bi al-Lisân disini adalah apakah ceramah-ceramah agama yang dilakukan oleh para Da'i dan Da'iah muda pilihan ANTV dan itu mempunyai manfaat nyata dan bukan hanya sekedar informasi verbal semata terhadap objek dakwah.

Menurut Yunan Yusuf dan buku Metode Dakwah adalah Dakwah bi al-Lisân dapat dinyatakan efektif bilamana:

- Berkaitan dengan acara-acara ritual seperti khutbah Jum'at, khutbah 'Idul Fitri atau 'Idul 'Adha, dst.

- Kajian materi yang disampaikan berupa tuntunan praktis kepada mad'u.

- Disampaikan dalam konteks sajian terprogram secara rutin dan memakai al-Qur'an dan hadits sebagai sumber kajian.

- Disampaikan dengan sistem dialog dan maupun monolog, sehingga audiensi dapat memahami materi dakwah secara tuntas, setidak-tidaknya metode ceramah masih dapat dikatakan efektif kalau disampaikan secara komunikatif.

Dakwah bi al-Lisân dinyatakan kurang efektif bilamana:

- Diadakan secara rutin tetapi tidak terprogram, disamping oleh 
orang yang berbeda-beda sehingga sering terjadi duplikasi materi dari orang yang sama maupun dari orang yang berbeda.

- Disampaikan secara insidentil, seperti pada hari-hari besar Islam, meskipun manfaatnya juga besar terutama dari sisi syi'ar Islam, namun (serapan)-nya bagi mad'u kurang maksimal, terutama kalau tidak ada follow up-nya, bahkan bisa jadi terkesan mubazir (Hefni, 2003: viii).

Dakwah bi al-Hâl adalah dakwah dengan perbuatan nyata seperti yang dilakukan oleh Rasulullah SAW terbukti bahwa pertama kali tiba di Madinah yang dilakukan adalah pembangunan masjid Quba, mempersatukan kaum Anshar dan Muhajirin dalam ikatan ukhuwah Islamiyah. Bahwa dakwah bi al-Hâl ini ternyata sangat efektif, akan tetapi sebagian besar umat Islam kurang memperhatikan dakwah ini, sehingga mereka lebih suka berdakwah bi al-Lisân, padahal dakwah bi al-Lisân dan dakwah bi al-Hâl satu kesatuan yang tidak dapat dipisah-kan dalam diri seorang Da'i maupun Da'iah.

Dakwah menurut Natsir (2000: 109) adalah amar ma'rûf nahi munkar, yakni syarat mutlak bagi kesempurnaan dan keselamatan hidup masyarakat ini adalah kewajiban sebagai pembawaan fitrah manusia selaku "social being", (makhluq ijtimâ'î) dan umat Islam adalah pendukung amanah untuk meneruskan risalah dengan dakwah, baik sebagai ummat kepada umat-umat yang lain, ataupun selaku perseorangan di tempat manapun mereka berada, menurut kemampuan masing-masing, seperti sabda Rasulullah SAW: Artinya: "Sampaikanlah apa yang kamu terima dari padaku walaupun satu ayat."

Hadits di atas mengandung paling tidak dua makna, pertama, bahwa menyampaikan ajaran Islam baik ayat maupun hadits adalah kewajiban setiap muslim/muslimah. Kedua, dakwah dengan kata-kata yang isinya pesan-pesan agama baik dalam bentuk ceramah, diskusi, pesan-pesan pendek atau tulisan adalah hal yang diperintahkan, karena substansinya menyampaikan dakwah atau tablihg tidak bisa dipisahkan dari komunikasi, ia perlu cara, metode, dan tentu saja materi yang benar dan tepat.

Sementara "ideologi" industri media massa adalah profit yang tinggi atau acara yang memiliki nilai jual tinggi. Untuk itu dakwah haruslah dikemas dengan cara dan metode yang tepat dan menarik, 
dakwah harus tampil secara aktual, faktual, dan kontekstual. Aktual dalam arti memecahkan masalah kekinian yang hangat di tengah masyarakat, faktual dalam arti konkrit dan nyata, serta kontekstual dalam arti relevan dan menyangkut problema yang sedang dihadapi oleh masyarakat. Oleh sebab itu mengemas dakwah yang aktual, faktual dan kontekstual pada media televisi menjadi bagian strategis dari kegiatan dakwah itu sendiri, untuk menyajikan kemasan dakwah yang menarik dan menggugah masyarakat melalui televisi (Hefni, 2003: xiii).

Data terakhir menunjukkan bahwa saat ini ada sekitar 20-23 juta rumah tangga yang memiliki pesawat televisi dan tidak kurang dari 18 jam sehari berbagai acara dan informasi disajikan kepada para pemirsa di seluruh tanah air. Itu berarti hanya ada enam jam sehari semalam waktu luang, itu pun ketika jam tayang relatif sama, tapi ketika sudah mulai banyak stasiun TV yang non-stop, berarti waktu kosong melihat TV semakin mengecil.

Televisi kini telah menjadi kotak ajaib yang secara khusus berada di ruang rumah yang merupakan produk teknologi yang paling banyak menerima "gelar kehormatan", seperti "Jendela dunia", "kotak informasi", atau "institusi hybrid". Keberadaan produk teknologi berupa televisi telah menjadi semacam "produsen kebudayaan", dilayar "kotak ajaib" tersebut selain informasi dan hiburan juga terdapat tempat pencitraan pengemasan sesuatu (Kusnawan, 2004: 74). Media komunikasi merupakan sebuah peralatan atau perlengkapan yang dimaksudkan untuk memudahkan keberlangsungan aktivitas berkomunikasi umat manusia (Sensa, 2005: 163).

\section{Da'i Muda Pilihan (DMP) ANTV 2011/2012}

Dasar pemikiran acara kontes Da'i Muda Pilihan (DMP) ANTV adalah kurangnya dai dan da'i muda Indonesia saat yang terekspos ke media televisi padahal realita menunjukkan banyak sekali bakat-bakat muda yang sangat potensial utuk di munculkan ketengah masyarakat melalui kemasan acara dakwah di media televisi, makanya motto DMP adalah "SAATNYA YANG MUDA BICARA". Kehadiran acara DMP di ANTV adalah ingin mengemas satu program dakwah/relegius dengan cara mencari bakat/talent scout, dan ternyata mendapat respons positif dari pemirsa dan juga menunjukkan performa yang baik dari segi perolehan rating dan share. Artinya, sebelum program Da'i Muda Pilihan ANTV ditayangkan di masyarakat, program keagamaan (relegius) di televisi kurang mendapat tempat yang layak, selalu menjadi nomor kesekian, tapi 
dengan adanya acara DMP ANTV image program religius agak terdongkrak dan menunjukkan jatidirinya sendiri, sehingga menjadi program yang menuntun dan layak diperhitungkan. Bahkan Grandfinal pun mendapat penghargaan dari MUI dan Kementerian Agama dengan memberikan penghargaan baik secara materil maupun moril kepada peserta DMP ANTV terbukti dengan kehadiran para tokoh MUI dan Menteri Agama secara langsung ke stasiun ANTV untuk menyaksikan acara kontes DMP ANTV.

Terbukti pula dengan populernya kontes Da'i Cilik DACIL ANTV yang sudah terlebih dahulu penyelenggaraannya dan juga mendapat sambutan yang luar biasa di masyarakat dengan besarnya dukungan langsung maupun tidak langsung. Melihat fenomena ini umat Islam patut bersyukur, karena ternyata ANTV tetap mampu menunjukkan keunggulan sebagai pioneer dalam berkreativitas mengemas program dakwah secara menarik melalui media televisi.

Dasar pelaksanaan program DA'I MUDA PILIHAN ANTV 2011/1012 dengan motto "SAATNYA YANG MUDA BICARA", adalah apresiasi dan aplikasi langsung firman Allah SWT dalam QS: an-Nahl: 125: "Artinya serulah kejalan Tuhan dengan cara yang bijak dan nasehat yang baik". Dan Hadits Rasulullah Saw yang berbunyi: "Artinya, Sampaikanlah pesanku walaupun hanya satu ayat". Hadits inilah yang menginspirasi tim kreatif dan petinggi ANTV maju dengan niat baik untuk menyelenggarakan acara DMP ini. Bebagai persiapan dan kegiatan dilakukan dalam rangka mensukseskan DMP ANTV diantara-nya menciptakan dan menjadi lagu soundtreck acara DA'I MUDA PILIHAN ANTV.

Lebih dari itu ANTV sudah sangat dikenal oleh masyarakat luas sebagai televisi audisi pencari bakat dan memformat acara secara live contest terbukti memiliki nilai dramatik tinggi, dan juga melibatkan instruktur yang ahli di bidangnya masing-masing sehingga menambah nilai jual program. Disamping itu ANTV melibatkan pemirsa secara langsung melalui SMS, juga bisa mengikat minat menonton program DMP ANTV secara rutin. Tidak dapat dipungkiri bakwa acara yang disiarkan secara live mempunyai suatu kekuatan dalam menarik pemirsa karena penonton diajak menyaksikan langsung kontes DMP di studio, bahkan bagi mereka yang berada dirumah atau dalam perjalanan juga merasa lebih dekat dengan siaran yang sedang berlangsung apalagi pemirsa dijadikan pengamat aktif dengan mengirim pesan singkat/SMS kepada 
da'i dan da'iah favorit mereka.

Untuk itu peserta yang terpilih berdasarkan standarisasi tertentu ketika audisi, ini terbukti dalam wilayah survei AC Nielsen yang juga merupakan kota berbasis Islam kuat, seperti Makassar, Medan, Banjarmasin, Palembang, Surabaya, Bandung, Jakarta, dan Riau, dan ini akan memunculkan da'i dan da'iah baru yang akan menyebarkan Islam secara luas dan menjadi idola baru dalam masyarakat dan memiliki massa, karena tidak dapat di pungkiri bahwa masyarakat sekarang ini cenderung mengidolakan da'i-da'i muda seperti Ustad Nur Maulana, Ustad Solmed, Ustazd Jefri, Arifin Ilham, Aa Gym, Yusuf Mansyur, Koko Liem dan lain-lain. Maka wajar ANTV melakukan sistem seleksi begitu ketat sehingga dari 1500 paserta dari kota-kota audisi dan setelah melalui beberapa tahap seleksi, akhirnya yang terpilih menjadi kontestan hanya 10 orang dari laki-laki (da'i) dan 10 orang dari perempuan (da'iah) untuk tampil berdakwah di ANTV sampai tahap Grandfinal denga hadiah materi yang sangat menggiurkan yaitu tabungan 75 Juta bagi pemenang pertama ditambah lagi hadiah Haji plus, beasiswa studi strata satu dan strata dua, serta buku Esiklopedia Islam yang nilainya jutaan serta hadiah hiburan lainnya. Sementara pemenang kedua mendapat hadiah tabungan sebesar 50 juta, Haji Plus, beasiswa Strata 1 dan strata 2, juga buku Ensiklopedi Islam, kemudian pemenang ketiga sama hanya sedikit berbeda di tabungan saja hanya 30 juta rupiah. bagi yang menang sampai Grandfinal dalam kompetisi DMP ANTV ini juga akan di masukkan dalam manajemen acara keagamaan ANTV untuk diorbitkan menjadi da'i-da'iah muda masa depan di Indonesia. Adapun 17 orang kontestan yang lebih dahulu gugur dalam kompetisi masing-masing hanya mendapatkan uang tabungan senilai lima juta rupiah. Semua hadiah dipersembahkan oleh pihak sposor acara DMP ANTV 2011/2012.

Da'i dan dai'ah televisi perlu orang yang memiliki kemampuan dan keterampilan khusus, disamping persyaratan penampilan dan suara yang prima, berkepribadian dan mempunyai intelekual yang luas, karena da'i atau da'iah televisi pada dasarnya berkomunikasi dengan khalayak melalui lisan atau ucapan, sikap dan perilaku, penampilan dan kepribadiannya. Oleh karena itu bagi para da'i dan da'iah televisi diperlukan kematangan dalam hal:

- Penampilan yang prima

- Volume suara standar siaran

- Berkepribadian yang kuat 
- Intelektualitas yang tinggi

- Emosionalitas yang cerdas

- Spiritualitas yang peka

- Kemampuan berbahasa yang memadai (Kusnawan, 2004: 78).

Menurut hemat penulis untuk menjadi seorang dai yang handal berbicara di depan massa diperlukan syarat-syarat:

- Mahir memilih dan menyusun kalimat dengan baik.

- Mahir membangkitkan imajinasi penonton dengan kata-kata dan kalimat

- Mahir mengekspresikan situasi dengan kata-kata dan memberikan aksentuasi secara tepat pada bagian-bagian yang di rasa penting.

Sekilas tentang kontestan Da'i Muda Pilihan ANTV, mereka yang terpilih masuk 10 besar Da'i dan 10 besar Da'iah merata dari seluruh kota yang di audisi, diantaranya; Jakarta, Bandung, Semarang, Surabaya, Makassar, dan Riau. Namun ada beberapa yang unik dari para fnalis yaitu berkaitan dengan latar belakang kehidupan mereka setelah lolos masuk 10 besar kontestan diantaranya berlatar belakang sisi pen-didikan; diantara kontestan ada yang kuliah strata dua dan di perguruan tinggi strata satu baik di perguruan tinggi negeri maupun swasta, ada juga beberapa diantara peserta kontestan yang masih sekolah menengah atas, serta masih studi di pondok pesantren. Kemudian ditinjau dari latar belakang status ekonomi hampir semua kontestan dari kalangan ekonomi menengah ke bawah, bahkan ada diantara kontestan da'i yang mempunyai masa lalu yang kelabu yaitu mantan pelaku kriminal, tapi kemudian mendapat hidayah dan bertaubat lalu berdakwah dan lolos masuk audisi 10 besar DMP ANTV 2011/2012.

Untuk memantapkan aqidah dan keilmuan serta ibadah-ibadah mahdhah maupun ghair mahdhah termasuk kegiatan sosial keagamaan di masyarakat, peserta DMP ANTV di karantina di dua lokasi khusus yaitu di Komplek kampus TAZKIYA Sentul Jawa Barat dan di Apartemen Aston Rasuna Kuningan Jakarta, agar peserta DMP ANTV bisa lebih khusyuk dan tenang dalam melakukan kegitan belajar yang sudah di program oleh pihak ANTV. Para kontestan hanya keluar Karantaina untuk live show di studio Episentrum Kuningan Stasiun ANTV dan melaksanakan tugas kegiatan sosial keagamaan dimasyarakat tertentu pastinya dalam pengawasan dan pengawalan oleh pihak kru DMP ANTV. Selama karantina para peserta finalis juga mendapat ilmu public speaking dan 
broadcasting dari pakar-pakar yang handal: mereka diajarkan cara berpenampilan fisik yang sempurna, cara memulai pidato atau ceramah yang menarik, sampai pada cara gesture yang indah dan komunikatif bukan hanya verbal tapi juga non-verbal (body languge), sehingga peserta matang sebagai da'i dan dipadu dengan seni.

Kondisi di atas hanya berlangsung tidak lebih dari enam bulan sampai acara DMP selesai (terpilih pemenang satu, dua, dan tiga). Para kontestan sangat bersemangat dalam kompetisi DMP ANTV ini karena disamping ketenaran yang akan mereka dapatkan karena diorbitkan oleh media televisi (ANTV). Setelah penulis mewawancarai Eksekutif Produser dan Produser DMP ANTV 2011/2012, maka sampailah pada tujuan dari penyelenggaraan DMP ANTV ini adalah sebagai wadah pencarian bakat da'i dan da'iah untuk regenerasi da'i dan da'iah dalam rangka mensyiarkan agama Islam lebih luas dengan cara efektif dan professional melalui media televisi. Hemat penulis keberadaan acara DMP ANTV 2011/2012 perlu mendapat perhatian besar oleh umat Islam khususnya dan contoh tauladan oleh generasi masa depan agar agama Allah tetap tegak dengan dakwah yang dikemas melalui media televisi yang telah dipelopori oleh ANTV.

\section{Kode etik Da'i dan Da'iah}

Dakwah Islam itu harus dijalankan dengan benar dan serius, melalui aturan-aturan yang benar pula sehingga diterima dengan komitmen yang sama terhadap kebenaran Islam. Obyek dakwah harus merasa bebas dari paksaan, ancaman serta nilai-nilai yang bersifat merusak dan cendrung untuk anarki atau menang sendiri. Karena itu para pelaku dakwah dalam hal ini da'i tidak diperintahkan menyeru Islam begitu saja, ada aturan-aturan yang telah ditetapkan.

Syarat-syarat dakwah yang telah ditetapakan oleh Allah dan mereka mengemban wewenang yang sama dengan perintah dakwah. "tidak ada paksaan dalam agama, kebenaran telah nyata, barang siapa menghendaki biarlah dia beriman, barang siapa tidak menghendaki biarlah dia kafir, maka yang beruntung adalah dirinya sendiri dan barang siapa yang menolaknya, maka yang celaka adalah dirinya sendiri" (Q.S. 2: 256, lihat juga Q.S. 18: 29, 39:41)

Jelas dakwah Islam tidak bersifat memaksa, melontarkan isu-isu yang bersifat fanatis, provokatif, celaan-celaan yang menimbulkan permusuhan dan bukan pula aktivitas-aktivitas yang bersifat destruktif. Karena etika manusia memandang dakwah yang dipaksakan sebagai 
pelanggaran berat, maka itu dakwah Islam mengkhususkan penggunaannya secara persuasif.

Da'i dan da'iah secara khusus adalah orang yang harus terlatih dalam menyampaikan ajaran Islam, oleh karena itu dalam pandangan Saputra (2010: 4) seorang dai dituntut harus memahami ajaran Islam dengan sungguh-sungguh, berikut hal-hal yang perlu diperhatikan oleh da'i dan da'iah:

- Beriman dan bertaqwa kepada Allah SWT;

- Mempunyai niat yang ikhlas;

- Selalu bertaqarrub kepada Allah;

- Menghiasi diri dengan akhlaq muliah;

- Memahami karakteristik jamaah atau obyek dakwah (mad'u);

- Memiliki pengetahuan agama Islam yang luas;

- Memberi suri tauladan yang baik .

Pengertian kode etik dan rambu-rambu etis dakwah harus dimiliki oleh seorang juru dakwah (Yusuf, 2002). Namun secara khusus dalam berdakwah terdapat kode etik tersendiri (Yakub, 1997: 36). Seorang Da'i atau muballigh dituntut untuk memiliki etika-etika yang terpuji dan menjauhkan diri dari perilaku-perilaku yang tercela, dan sumber ramburambu etis dakwah bagi seorang da'i atau da'iah adalah al-Qur'an seperti yang dicontohkan oleh Nabi Muhammad Saw, karena pada dirinyalah figur teladan bagi kehidupan yang diinginkan oleh Allah, dan pada diri Rasulullah telah mencapai puncak yang tinggi (Mansyur, 2000: 98). Adapun rambu-rambu etis menurut Hefni dkk. adalah sebagai berikut:

\section{a. Tidak memisahkan antara ucapan dan perbuatan}

Mencontoh Rasulullah dalam menjalankan dakwah, para da'i dan da'iah hendaklah tidak memisahkan antara apa yang dikatakan dengan apa yang ia kerjakan, ibarat seorang da'i atau da'iah yang tidak beramal sesuai dengan ucapannya seperti pemanah tanpa busur dengan demikian sulit dakwah mereka akan berhasil. Kode etik ini bersumber pada QS: al-Shaff: 2-3 sebagai berikut: "Artinya: Hai Orang-orang yang beriman mengapa kalian katakan hal-hal yang kalian tidak melakukannya? Amat besar murka di sisi Allah, bahwa kalian mengatakan apa-apa yang kalian tidak kerjakan". Dari ayat ini dapat dipahami bahwa dakwah haruslah dimulai dari pribadi sang da'i dan da'iah, sebelum mengubah akhlak orang lain seorang da'i atau da'iah harus mampu mengubah akhlak dalam dirinya terlebih dahulu, senada dengan firman Allah dan 
QS: al-Baqarah: 44 bahwa dakwah itu merupakan sebuah proses yang kontinyu dan bukan merupakan pekerjaan yang mudah (Shihab, 1999: 24). Pada intinya antara ucapan dan perbuatan harus merupakan satu sisi mata uang yang sama dan harus direalisasikan oleh da'i atau da'iah.

\section{b. Tidak melakukan toleransi agama}

Toleransi memang dianjurkan oleh Islam tetapi hanya dalam batasbatas tertentu dan tidak menyangkut masalah agama/keyakinan, Islam memberikan garis tegas untuk tidak bertoleransi dalam hal keyakinan seperti dalam QS: al-Kafirun: 1-6.

"Artinya: Katakanlah: hai orang-orang yang kafir, aku tidak akan menyembah apa yang kamu sembah. Dan kamu bukan penyembah Tuhan yang aku sembah. Dan aku tidak pernah menjadi penyembah apa yang kamu sembah, dan kamu tidak pernah pula menjadi penyembah Tuhan yang aku sembah. Untukmulah agamamu, dan untukkulah, agamaku"

Pada tataran ini seorang da'i dan da'iah harus teguh dan tegas dalam mempertahankan prinsip aqidahnya dan tampil dengan penuh kejujuran dalam menyampaikan dakwahnya, namun juga tidak boleh memaksa para mad'unya untuk mengikuti jalannya karena jelas tidak ada pemaksaan dalam agama, karena Allah sendiri memberikan kemerdekaan penuh bagi manusia untuk percaya atau tidak terhadap ajaran Nabi Muhammad Saw. (Fadhullah, 1997: 47). Kemerdekaan ini, menurut Nasution (1993: 275) sekaligus memperkuat statement yang ada dalam surah al-Kafirun. Karena manusia telah dewasa dan dibekali akal dan tidak perlu dipaksa, dan Islam merupakan agama kemanusiaan dalam arti bahwa ajaran-ajarannya sejalan dengan kecenderungan alami manusia menurut fitrahnya yang abadi (perenial) (Madjid, 2000: 24). Seruan menerima agama yang benar itu dikaitkan dengan fitrah QS: alRûm: 30 sebagai berikut:

"Artinya: Maka hadapkanlah wajahnu dengan lurus kepada agama Allah, tetaplah atas fitrah Allah yang telah menciptakan manusia menurut fitrah itu. Tidak ada perubahan pada fitrah Allah. Itulah agama yang lurus tetapi kebanyakan manusia tidak mengetahui".

\section{c. Tidak menghina sesembahan non muslim}

Kode etik ini diambil dari QS. al-An'am; 108: “Artinya, dan janganlah kamu memaki sesembahan yang mereka sembah selain Allah, karena mereka nanti akan memaki Allah dengan melampaui batas tanpa 
pengetahuan". Peristiwa ini berawal ketika pada zaman Rasulullah orangorang muslim pada saat itu mencerca berhala-berhala sembahan orangorang musyrik. Dan akhirnya karena hal itu menyebabkan mereka mencerca Allah, maka Allah menurunkan ayat ini. Da'i dan dai'ah dalam menyampaikan ajarannya sangat dilarang untuk menghina ataupun mencerca agama lain. Karena tindakan mencaci atau menghina tersebut justru akan menghancurkan kesucian dakwah dan sangatlah tidak etis. Pada hakekatnya seorang da'i atau da'iah harus menyebarkan Islam dengan cara aman dan damai, bukan dengan cara menyebarkan kejelekan terhadap umat lain.

\section{d. Tidak melakukan diskriminasi sosial}

Apabila menelusuri tauladan Rasulullah maka da'i dan da'iah hendaknya tidak membeda-bedakan atau pilih kasih antara sesama manusia, baik kaya maupun miskin, kelas elite maupun kelas marginal (pinggiran) atau status lainnya yang menimbulkan ketidakadilan. Semua harus mendapatkan perlakuan yamg sama, karena keadilan sangatlah penting dalam berdakwah, da'i maupun da'iah harus menjunjung tinggi hak universal manusia dalam berdakwah (Marlow, 1999: 32). Karena itu merupakan hal yang suci dan sangat dihargai oleh setiap orang tanpa memandang kelas. Islam sendiri tidak mendukung prinsip hierarki dalam mayarakat (al-Faruqi, 1998: 302). Islam dalam menegakkan hubungannya dengan manusia adalah sama, hubungan tersebut merupakan fungsi kemakhlukan manusia dalam sebuah konsensus. Disamping itu dakwah tidak ada istilah class society yang ada adalah classless society yaitu masyarakat tanpa kelas yang struktur di dalamnya tidak ada pembedaan antara elite dan non elite yang mengandung prinsip equal dan justice, kesederajatan dan keadilan (QS: al-An'âm:52 dan QS: alKahfi: 28) dan kode etik ini didasarkan pada QS: Abasa:1-2, QS: Sabâ': 47, QS: al-Syu'arâ: 104, 127, 145, 164, 180, QS: Hûd: 29-51.

\section{e. Tidak memungut imbalan}

Pada tataran ini memang masih ada perbedaan pendapat tentang dibolehkannya ataupun dilarang dalam memungut biaya atau dalam bahasa lainnya memasang tarif, dalam hal ini ada tiga pendapat dari kalangan ulama:

- Mazhab Hanafi berpendapat bahwa memungut imbalan dalam berdakwah hukumnya haram secara mutlak, baik dengan perjanjian sebelumnya maupun tidak. 
- Imam Malik bin Anas, Imam Syafi'i membolehkan dalam memungut biaya atau imbalan dalam menyebarkan ajaran Islam baik ada perjanjian sebelumnya maupun tidak.

- Al-Hasan al Bisri, Ibn Sirin, al-Syaibi dan lainnya, mereka berpendapat boleh hukumnya memungut bayaran dalam berdakwah, tetapi harus diadakan perjanjian terlebih dahulu (Hefni, 2003: 90).

Perbedaan pendapat dari para ulama bisa terjadi karena banyaknya teks-teks al-Qur'an yang menjadi sumber etika sehingga muncul perbedaan atau penafsiran atau pemahaman yang berbeda pula. Namun dalam konteks kekiinian imbalan jasa dalam berdakwah itu merupakan salah satu dukungan finansial dalam melaksanakan dakwah itu sendiri. Dalam artian dakwah pada era sekarang dukungan finansial itu sangat penting karena akan menambah sumberdaya sang da'i dan da'iah tersebut dari segi keilmuan, kesejahteraan hidup dan proses aktivitas dakwah. Professionalitas seorang da'i atau da'iah ini sangatlah penting, asalkan da'i mampu memberikan apa yang dibutuhkan oleh mad'û/masyarakat. Dalam konteks ini tidak dapat dihubungkan dengan keikhlasan, sebab keikhlasan da'i atau da'iah itu tidak dapat dijadikan sebuah barometer, karena hal tersebut merupakan sebuah hubungan secara vertikal antara da'i dengan Tuhannya.

\section{f. Tidak berteman dengan pelaku maksiat}

Berkawan dengan orang-orang pelaku maksiat ini dikhawatirkan akan berdampak buruk atau serius. Karena orang bermaksiat itu beranggapan bahwa seakan-akan perbuatan maksiatnya direstui oleh dakwah, pada sisi lain integritas seorang da'i atau da'iah tersebut akan berkurang, kode etik ini didasarkan pada QS: al-Maidah: 78 sebagai berikut: "Artinya: Telah dilaknati orang-orang kafir dari Bani Israil dengan lisan Daud dan 'Isa putra Maryam, yang demikian itu disebabkan mereka durhaka dan selalu melampauhi batas" (Hefni, 2003: 92).

Dalam kode etik ini jika da'i atau da'iah terpaksa harus terjun ke lingkungan pelaku maksiat, maka da'i maupun da'iah harus mampu menjaga dirinya serta mengukur kemampuannya, dalam artian jika sang da'i atau da'iah merasa tidak mampu untuk berdakwah di tempat tersebut ia harus meninggalkannya karena dikhawatirkan akan terpengaruh dengan komunitas tersebut, dan di sisi lain berkawan dengan pelaku maksiat dikhawatirkan akan menjatuhkan integritas dari sang da'i

$1 6 \longdiv { \text { Ilmu Dakwah : Academic Journal for Homiletic Studies Vol. } 6 \text { No. } 1 \text { | Juni } } 2 0 1 2$ 
dalam masyarakat.

\section{g. Tidak menyampaikan hal-hal yang tidak diketahui.}

Da'i atau da'iah yang menyampaikan suatu hukum, sementara ia tidak mengetahui, hukum itu pasti akan menyesatkan umat, seorang juru dakwah tidak boleh menjawab pertanyaan orang menurut seleranya sendiri tanpa ada dasar hukumnya. Da'i atau da'iah juga harus menyampaikan pesan dakwah sesuai dengan kemampuannya, masingmasing tidak memasakan sesuatu yang berada di luar kesanggupan mereka. Hal ini didasarkan pada QS. al-Isra: 36; “Artinya, Dan janganlah kamu mengikuti apa yang kamu tidak mempunyai pengetahuan tentangnya, sesungguhnya pendengaran, penglihatan dan hati semuanya akan dimintai pertanggung jawabannya".

Oleh karena itu seorang da'i dan da'iah harus memiliki bekal ilmu yang cukup dan mereka harus bisa mengakomodir permasalahan yang terjadi dalam masayarkat. Untuk itu sangat diperlukan kecerdasan dan ilmu pengetahuan serta pandangan dan strategi dakwah yang jitu. Sasmita (1997: 93) menguraikan sifat-sifat kecerdasan da'i atau da'iah yang harus dimilki diantaranya:

- Seorang da'i haruslah pandai dalam arti memilki pandangan yang luas dalam merespon dan menangani peristiwaperistiwa yang terjadi pada umat.

- Memiliki pandangan, firasat, sikap terhadap setiap urusan atau permasalahan.

- Da'i haruslah mampu menangkap hal-hal yang tersembunyi di balik peristiwa.

- Mampu mengambil manfaat dari setiap peristiwa yang terjadi.

Islam merupakan elan vital dalam setiap perubahan sosial, bisa dikatakan kode etik ini merupakan salah satu cermin usaha ilmiah yang harus dimiliki oleh sang da'i dan da'iah dalam mengemban tugas dakwah, sebab dakwah dibutuhkan sebuah sikap intelektual yang tinggi (Rafiuddin dan Jalil, 1997: 85-86).

Dari sini jelas bagi insan dakwah mengenai etika atau kode etik dakwah, semuanya telah bersumber pada al-Qur'an dan hadits, cara yang Qur'ani ini harus menjadi pegangan bagi setiap juru dakwah dalam mengahadapi umat manusia sesuai dengan kondisi yang dihadapinya dengan sifat arif dan lembut dengan penuh kesabaran (Yakub, 1983: 49).

\section{Kepribadian yang harus dimiliki da'i dan da'iah}


Terbentuknya sifat dan perilaku akibat pengaruh yang ditimbulkan oleh aktivitas berkomunikasi, maka Allah menetapkan seperangkat sikap, sifat dan perilaku yang harus dimiliki oleh para juru dakwah, dalam berdakwah secara pasti menggunakan indera-indera diantaranya pendengaran dan penglihatan, seperti Allah kemukakan dalam QS: AzZumar: 18 yang artinya:

"Orang-orang yang mendengarkan perkataan, lalu mengikuti apa yang paling baik diantaranya, mereka itulah orang-orang yang diberi oleh Allah petunjuk, dan mereka itulah orang-orang yang mempunyai akal yang dicerahkan".

Sebagaimana diuraikan oleh Sensa (2005: 167), pengertian orangorang yang mempunyai akal yang dicerahkan dalam ayat di atas adalah diistilahkan ulûl-albâb karena ulûl albâb memiliki kepribadian sebagai berkut:

- $\quad$ Dapat menangkap hakikat hukum Qishash yang mengandung makna kehidupan di dalamnya (2: 179)

- Membekali diri dengan bekal terbaik berupa ketaqwaan kepada Allah SWT (2: 197)

- Dapat mengambil pelajaran dari Allah SWT (2: 269, 3: 7, 13: 19, 38: 9)

- Mampu memahami fenomena alam sebagai ayat-ayat Allah (3: 190)

- Dapat mengambil pelajaran dari al-Qur'an (14:52)

Dalam tulisan Arsyad di Majalah NooR (2006: 14), pada tingkat global dakwah diera teknologi sekarang ini harus dibantu dengan menguasai teknologi media. Media itu "store the image" yang mampu memberi kesan dan membentuk imej dan itu mampu mengubah orang. Untuk itu seorang da'i atau da'iah jika ingin berdakwah setidaknya harus memulai dengan:

- Niatnya ikhlas karena Allah semata.

- Punya kemampuan diri (inner capacity) dalam pengetahuan tentang agama Islam.

- Berhati bersih jauh dari segala penyakit hati (sombong, iri, dengki, dendam).

- Cocok antara perkataan dan perbuatan terutama dalam kehidupan sehari-hari. 
- Menjadi teladan bagi diri, keluarga dan masyarakat (Da'i dan Da'iah harus menjadi role model).

- Punya kemauan, sebab tanpa kemauan yang teguh dakwah akan berhenti kala mendapat rintangan.

- Professional dalam mengelola dakwah, melayani dakwah, dan memasarkan dakwah (how to manage, how to serve, how to market).

- Kekuatan ruh, hal terpenting dalam berdakwah karena ruh/spirit yang diberikan Allah akan menjadi kekuatan dalam berdakwah, maka da'i dan da'iah harus bayak berdoa dan mendekatkan diri pada Allah SWT.

\section{Sifat-sifat Juru Dakwah}

Ada banyak perilaku kehidupan Rasulullah Saw yang mesti diteladani seorang da'i. Diantara sifat-sifat Rasulullah yang harus diteladani dan diterapkan dalm kehidupan kini:

- Siddiq-Transparansi: merupakan kunci sukses dalam berbagi segi kehidupan. Orang yang jujur dan terbuka akan memiliki wawasan hidup yang jernih, karena tidak terkotori oleh upaya untuk menutupi, menyembunyikan sesuatu, memanipulasi dan berbohong.

- Amanah-Kompetensi: kemampuan atau kompetensi ini dapat berupa kemampuan teknis (keahlian) dan juga kompetensi yang bersifat moral yang bersifat moral yakni memilki komitmen dan kesungguhan dalam melaksanakan amanah.

- Tabligh-Komunikasi: kemampuan berkomunikasi akan memungkinkan terlaksananya berbagai gagasan dan cita-cita luhur, paling tidak komunikasi atau tabligh dapat menjadi sarana untuk hal-hal berikut: mengumpulkan informasi dan mengenai masalah, menghimpun dukungan dan partisipasi, mengelola pekerjaan besar secara kolektif dan menyampaikan pesan moral agama.

- Fathanah-Intelegensi: intelegensi dibutuhkan untuk menghadapi masalah-masalah yang besar dan kompleks, serta tantangan-tantangan yang datangnya mendadak. Pendeknya, intelegensi dibutuhkan untuk menghadapi hal-hal yang tidak biasa yang membutuhkan intelegensi yang cukup untuk bisa menata sumber daya dan mengatur straegi agar dapat 
bertahan dan melaksakan misi secara baik. Bagi seorang da'i atau da'iah ada tiga unsur utama: kecerdasan bawaan, informasi, dan bimbingan Ilahi. Tentunya intelegensi itu perlu ditingkatkan dan diasah dengan cara mengasah kecerdasan melalui pendidikan formal dan non formal, menghimpun informasi dan mengharap bimbingan Ilahi.

Manusia diciptakan oleh Allah dengan kesempurnaanya yaitu diberinya manusia hati dan akal fikiran untuk melengkapi kekhalifahannya di muka bumi. Kerja dakwah adalah kerja menggarami kehidupan umat manusia dengan nilai-nilai iman, Islam dan takwa demi untuk kebahagiaan di dunia dan akhirat, kerja ini tidak akan pernah mati selama denyut nadi kegiatan manusia berlangsung, selama itu pula umat manusia berkewajiban menyampaikan pesan risalah nabi dan juga pesan al-Qur'an dalam kondisi an situasi apapun. Dalam pandangan al-Qur'an ucapan yang terbaik adalah ucapan yang menyeru kepada Allah dan beramal shaleh.

\section{Kesimpulan}

Dakwah hakikatnya adalah segala aktivitas dan kegiatan yang mengajak orang untuk berubah dari suatu situasi yang mengandung nilai kehidupan yang bukan Islami kepada nilai kehidupan yang Islami. Aktivitas dan kegiatan tersebut dilakukan dengan mengajak, mendorong, menyeru, tanpa tekanan, paksaan dan provokasi, dan sebagainya.

Fenomena di atas mencuatkan harapan besar bagi Islam sebagai agama yang menjunjung tinggi penghayatan nilai-nilai kebenaran universal, ledakan informasi bisa dijadikan medium penyampaian dan penyebar nilai-nilai Islam ke khalayak luas. Masyarakat pun sudah bergerak sangat kritis, masyarakat tidak lagi mengenal dan menganut satu nilai, mereka bisa memilih dan menilai dan pada akhirnya menentukan sikap untuk menerima dan meninggalkan apa yang menurut mereka sesuai keinginannya atau tidak sesuai keinginannya. Pada titik ini yang menjadi pertanyaan kemudian adalah apakah masyarakat yang menetukan posisi nilai tawar dakwah atau dakwah yang menggiring masyarakat pada pilihan yang seharusnya mereka terima, tentu saja semuanya tidak berlangsung sederhana, ledakan media yang tidak terbendung menjadi kiblat pembentukan nilai dan itu harus direspon secara arif dan bijaksana terlebih bagi praktisi dakwah. 
Untuk merancang strategi dakwah yang jitu dan tepat, maka diperlukan pembenahan dan pembinaan secara internal terhadap beberapa unsur yang terlibat dalam proses dakwah diantaranya; da'i dan da'iah (aktivis dakwah), materi dakwah, metode dakwah dan media dakwah (Azhar, 2003: 12-13). Salah satu pembenahan dan pembinaan juru dakwah yang handal untuk masyarakat sekarang dan akan datang, stasiun ANTV mengemas dakwah dalam bentuk kompetisi atau DMP ANTV. Salah satu tujuan kontes da'i dan da'iah ini adalah untuk meningkatkan sumber daya mubaligh dalam rangka mencapai tujuantujuan dakwah secara maksimal, maka dakwah perlu didukung oleh da'i dan da'iah yang handal.

Kehandalan tersebut merupakan kualitas yang seharusnya dimiliki oleh seorang juru dakwah sesuai dengan kebutuhan mad'û sekarang. Aktivitas dakwah harus dipandang sebagai kegiatan yang memerlukan keahlian dan keprofesionalan, maka para aktivis dakwah harus memiliki kualifikasi dan persyaratan akademik dan empirik dalam melaksanakan dakwah khususnya di media televisi (Muhyiddin, 2002: 34). Di era modern ini juru dakwah perlu memiliki dua kompetensi dalam melaksanakan dakwah yaitu: kompetensi substantif dan kompetensi metodologis. Kompetensi substantif meliputi penguasa-an ajaran-ajaran Islam secara tepat dan benar sedangkan kompetensi metodologis meliputi kemampuan dalam mensosialisasikan ajaran-ajaran Islam kepada sasaran dakwah (Mulkhan, 1996: 237).

Pemanfaatan teknologi modern sebagai media dakwah, salah satu sarana yang paling efektif untuk menyebarluaskan ajaran Islam adalah teknologi modern dibidang informasi dan komunikasi. Kemajuan di bidang informasi dan telekomunikasi harus dimanfaatkan oleh para praktisi sebagai media dalam melakukan dakwah Islam. Dengan cara demikian ajaran Islam dapat diterima dalam waktu yang relatif singkat oleh sasaran dakwah.[] 


\section{DAFTAR PUSTAKA}

'Abd al-Khaliq, Abd al-Rahman. (1983). Fushul min al-Siyasah alSyar'iyyah fi al-da'wah ila Allah. Kuwait: Jamiyyah Ihya' al-Turats alIslami

Al-Faruqi, Ismail Raji dan Al-Faruqi, Lois Lamya. (1986). The Cultural Atlas of Islam. New York: Macmillan Publishing Company

Al-Faruqi, Lois Lamnya. (1998). Atlas Budaya Islam. Menjelajah Khazanah Kehidupan Gemilang Islam. Bandung: Mizan

Al-Ghazali, Muhammad. (t.th.). Kifah Din. Beirut: Dar al-Kutub al-Haditsah

Arnold, Thomas W. (1995). The Preaching of Islam: A History of The Propagation of The Muslim Faith. Delhi: Low Price Publication

Azhar, M. (2003). 'Beberapa Catatan tentang Problematika Dakwah.' Dalam Majalah Suara Aisyiyah, No.2. Yogyakarta

Fadhullah, Muhammad Husain. (1997). Metodologi Dakwah dalam alQur'an. t.tp.: Lentera Basritama

Hefni, Harjani, dkk. (2003). Metode Dakwah. Jakarta: Kencana

Kusnawan, Aep, et al. (2004). Komunikasi Penyiaran Islam. Bandung: Benang Merah Press

Mahfudz, Syekh 'Ali. (t.th.). Hidayah al-Mursyidin ila Thuruq al-Wa'zh wa al-Khithabah. Beirut: Dar al-Ma'rifah

Mahmud, Ali 'Abd Halim. (1969). Ad-Da'wah al-Islamiyyah Da'wah Aalamiyyah. Kairo: Majelis al-A'la li Syu'un al Islamiyyah

Majalah NooR. (2006). Dakwah Era Milenium. edisi September

Majid, Nurcholis. (2000). Masyarakat Relegius. Jakarta: Paramadina

Mansyur, Syekh Mustofa. (2000). Fiqh Dakwah.Jakarta: Cahaya Ummat

Marlow, Loisen. (1999). Masyarakat Egaliter. Bandung: Mizan

Muhyiddin, Asep. (2002). Dakwah dalam Perspektif al-Qur'an. Bandung: Pustaka Setia

Mulkhan, Abdul Munir. (1996). Ideologisasi Gerakan Dakwah: Episode Kehidupan Muhammad Natsir dan Azhar Basyir. Yogyakarta: Sipress

Nasution, Harun. (1993). Islam Rasional. Bandung: Mizan

Natsir, Mohammad. (2000). Fiqhud Da'wah. cet. ke-11. Jakarta: Media

22 Ilmu Dakwah : Academic Journal for Homiletic Studies Vol. 6 No. 1 | Juni 
Dakwah

Poston, Larry. (1992). Islamic Da'wah in the West: Muslim Missionary Activity and the Dynamic of Conversion to Islam. New York: Oxford University Press

Rafudin dan Abdul Jalil, Maman. (1997). Prinsip dan Strategi Dakwah. Bandung: Pustaka Setia

Ridho, Adnan 'Ali. (1985). Daur al- Manhaj al-Rabbani fi ad-da'wah alIslamiyyah. Riyadh: Mathabi' al-Farazdaq al-Tijariyyah

Sadel, Hasan. (1996). Ensiklopedia Indonesia. Jakarta: Intermasa

Saputra, Wahidin. (2010). Retorika Monologika. Bogor: Titian Nusa Press (2011). Pengantar Ilmu Dakwah. Jakarta: Raja Grafindo Persada

Sasmita , M. Sobary. (1997). Tuhan Bernaungan Moral. Surabaya: Risalah Gusti

Sensa, Muhammad Djarot. (2005). Komunikasi Qur'aniyah. Bandung: Pustaka Islamika

Shihab, Alwi. (1999). Islam Inklusif: Menuju Sikap Terbuka dalam Beragama. Bandung: Mizan

'Umar Hasim, Ahmad. (1990). Ad-Da'wah al-Islamiyyah: Manhajuha wa Ma'alimuha. Kairo: Maktabah Gharib

Ya'qub, Hamzah. (1983). Etika Islam: Pembinaan Akhlaqul Karimah. Bandung: Diponegoro

Yakub, Ali Mustofa. (1997). Sejarah dan Metode Dakwah Nabi. Jakarta: Pustaka Firdaus

Yusuf, Yunan. (2002). Materi Kuliah Metode Dakwah. Jakarta: Pascasarjana UIN

Zaidan, Abd al-Karim. (1992). Ushul al-Dakwah. Baghdad: Dar al Wafa' 